\title{
Intestinal parasites in children, in highly deprived areas in the border region of Chiapas, Mexico
}

Emma Marianela Morales-Espinoza, MD, (1) Héctor Javier Sánchez-Pérez, M Sc, PhD, ${ }^{(2)}$

María del Mar García-Gil, MD, PhD, ${ }^{(3)}$ Guadalupe Vargas-Morales, $C$ hD, ${ }^{(2)}$

José Do mingo Méndez-Sánchez, ChD, ${ }^{(4)}$ Margarita Pérez-Ramírez, ChD.(4)

\section{Morales-Espinoza EM, Sánchez-Pérez HJ, García-Gil MM, Vargas-Morales G, \\ Méndez-Sánchez JD, Pérez-Ramírez M. Intestinal parasites in children, \\ in highly deprived areas in the border region of Chiapas, Mexico \\ Salud Publica Mex 2003;45:379-388.}

The English version of this paper is available too at: http://www.insp.mx/salud/index.html

\begin{abstract}
A bstract
Objective. To assess the prevalence of intestinal parasitic infections among children in highly deprived areas, and its possible association with demographic and socioeconomic indicators. Material and Methods. From March to September 1998 in a convenience sample of 32 communities of the border region of Chiapas, Mexico, selected at random based on the level of poverty and distance from the community to the nearest health care unit $(<1$ hour ; 1 hour or more), one of every four households with children under 15 years of age was randomly selected to provide three stool samples from their children (n 1478). Bivariate and multivariate (generalized linear models for correlated binary data) analysis were performed. Results. The glo bal prevalence of intestinal parasitosis was $67 \%$ (95\% confidence interval [CI] 64-70\%). Sixty percent had multiple parasites. The prevalence of Entamoeba histolytica/E dispar was $51.2 \%$, that of Giardia lamblia $18.3 \%$, and that of Ascaris lumbricoides $14.5 \%$. Multivariate analysis showed that age and speaking an indigenous language were significantly associated with the presence of $E$ histolytica/ $E$ dispar and Giardia lamblia.
\end{abstract}

\author{
Morales-Espinoza EM, Sánchez-Pérez HJ, \\ García-Gil MM,Vargas-Morales G, \\ Méndez-Sánchez JD, Pérez-Ramírez M. \\ Parasitosis intestinal en niños, \\ en áreas de alta marginación socioeconómica \\ de la región fronteriza de Chiapas, México. \\ Salud Publica Mex 2003;45:379-388. \\ El texto completo en inglés de este artículo también \\ está disponible en: http://www.insp.mx/salud/index.html
}

\section{Resumen}

Objetivo. Estimar la prevalencia de parasitosis intestinal en niños de zonas de alta marginación y su asociación con indicadores demográficos y socioeconómicos de interés. Material y métodos. En una muestra de 1478 menores de edad, de entre 1 a 14 años, provenientes de 32 comunidades de la región fronteriza de Chiapas, México, de mar$z 0$ a septiembre de 1998, se recolectaron tres muestras de heces fecales, seleccionadas aleatoriamente a partir del grado de marginación (alto y muy alto) del municipio al que pertenecen, y distancia de la unidad de salud más cercana a la comunidad ( $<1$ hora; 1 hora 0 más). En una de cada cuatro viviendas con niños menores de 15 años de edad, seleccionadas aleatoriamente, se obtuvieron tres muestras de heces fecales de éstos. Se efectuaron análisis bivariados con la prueba de ji cuadrada y multivariados con modelos lineales generalizados. Resultados. La prevalencia global de parasitosis fue de $67 \%$ (intervalo de confianza IC 95\% 64-70\%). Sesenta por ciento de los niños estaban multiparasitados. La prevalencia de Entamoeba histolytica/E dispar fue de $51.2 \%$, de Giardia lamblia, $18.3 \%$ y de Ascaris lumbri-

O ur special gratitude with the Barcelona Solidaria Program (through the Barcelona Municipal Institute of Health) and to the Mexican $\mathrm{N}$ ational Science and Technology Council (CONACYT, Mexico) for funding which made the present research possible.

(1) Facultad de Medicina. Medicina Preventiva y Salud Pública. Universitat Autónoma de Barcelona. Barcelona, España.

(2) El Colegio de la Frontera Sur, San C ristóbal de Las Casas, Chiapas, México.

(3) Unidad de Investigación. Hospital Universitario Dr. JTrueta, Girona,España.

(4) Instituto Nacional de Salud Pública, Centro de Investigación en Paludismo, Chiapas, México.

Received on: January 7,2003 • Acepted on: May 14,2003

Address reprint requests to: Héctor Javier Sánchez-Pérez. El Colegio de la Frontera Sur. Carretera Panamericana y Periférico Sur, S/N, 29290 San C ristóbal de Las Casas, Chiapas, México.

E-mail: hsanchez@ sclc.ecosur.mx 
Source of water and lacking a refrigerator and electricity were associated with the presence of Ascaris lumbricoides. Conclusions. Measures should be taken to improve water quality, sewage disposal, and domestic hygiene. Furthermore, health programs should be established to promote breast-feeding, and education policies aimed at reinforcing the use of indigenous languages by physicians in the health services. The English version of this paper is available too at: http://www.insp.mx/salud/index.html

Key words: intestinal parasitosis; poverty; child health; multivariate analysis; Mexico coides, $14.5 \%$. La mayor prevalencia de $\mathrm{E}$ histolytica/E dispar se asoció con la edad y hablar algún idioma indígena; la de Ascaris lumbricoides con el sitio de obtención de agua y la carencia de refrigerador y electricidad. Conclusiones. Es necesario hacer intervenciones locales de salud (calidad del agua, sistemas de desagüe), programas de educación sanitaria (promoción de la lactancia materna y medidas higiénicas) y promoción del habla de idiomas indígenas entre los médicos de la región. El texto completo en inglés de este artículo también está disponible en: http://www.insp.mx/salud/index.html

Palabras clave: parasitosis intestinal; pobreza; salud infantil; análisis multivariado; México
$\mathrm{P}$ arasitic infections occur worldwide, mainly affecting the poorer sectors of society. ${ }^{1}$ According to the World Health Organization (WHO), ${ }^{2}$ around 1 billion people are infected by Ascaris or Uncinarius, 500 million by Trichuris or amoebas, and 200 million by Giardia lamblia. Furthermore, there is a wide variability in both inter- and intra-regional parasitoses within a given country and among countries. ${ }^{3,4}$ These differences may be due to a variety of factors associated with the prevalence of these infections, such as soil composition, climate, and method of transmission, among others. Similarly, socioeconomic and health conditions, education and beliefs related to traditional health practices, as well as the presence of domestic animals in the home and contamination of water and food, have all been reported as factors associated with the presence of these diseases. ${ }^{3,4}$ Finally, age is also an associated factor related to the individual's immunologic status and behavioral patterns. One should also bear in mind that intestinal parasite infections are associated with poor physical growth and development, as well as with retardation of intellectual and cognitive development in children. ${ }^{5,6}$

Several estimates indicate that over a third (34\%) of the Mexican population is aged under 15 years and that more than $60 \%$ of Mexicans live in poverty. ${ }^{7}$ Within the Mexican Republic, Chiapas is one of the states with the worst conditions of poverty and socioeconomic deprivation (Table I). Additionally, Chiapas has a high proportion of indigenous population. ${ }^{12,13}$ In 1997 the death rate in Chiapas due to infectious intestinal diseases was the highest in the country, at 23.9 per 100000 inhabitants, while the national figure was 7.8 with the same denominator. ${ }^{14}$ The data recorded for 2000 showed the same situation (17.3 versus 5.8, respectively). ${ }^{9}$
A study carried out in Chiapas during $1994^{1}$ among the non-indigenous population revealed a higher prevalence of intestinal parasitosis -mainly due to Entamoeba histolytica-among children of poor peasants than among those of "rich" peasants. However, the few studies on parasites, which have been carried out in Mexico in recent years, have mainly focused on determining the prevalence of these infections without evaluating the associated epidemiological profile. ${ }^{15}$ Moreover, there are practically no studies addressing the magnitude of this problem in indigenous areas of high and very high levels of poverty.

In addition, Chiapas has a predominantly young population and the majority of its inhabitants live in poverty with a supply of water that is not only scarce but also deficient in quality. ${ }^{13,16}$ This population also has inadequate health coverage and scarcity of health resources. We decided to conduct a study to assess the health and living conditions in areas of high and very high poverty levels, ${ }^{17}$ in an attempt to contribute to the improvement of public health in Chiapas, Mexico. Our main objective was to assess the prevalence of intestinal parasitoses among children aged 1 to 14 years, and to determine its possible association with demographic and socioeconomic indicators in one of the regions of greatest poverty in Chiapas, -the region bordering Guatemala.

\section{Material and Methods}

The study was carried out from March to October 1998 in a convenience sample of 32 communities of the border region of Chiapas, located in the Southeastern part of the state, bordering Guatemala. This area is one of the poorest regions of Chiapas. The population of approximately 425000 inhabitants is conformed pre- 
Table I

\section{Demographic, socioeconomic, and health indicators of Chiapas and Mexico,1998}

\begin{tabular}{|c|c|c|}
\hline Indicator & Chiapas & Mexico \\
\hline \multicolumn{3}{|l|}{ Demographic } \\
\hline$\%$ of population $<14$ years $(2000) *$ & 38.0 & 33.4 \\
\hline$\%$ of indigenous population (5 and more years, 2000 )* & 26.4 & 7.5 \\
\hline Life expectancy at birth (years, 2002) $)^{\ddagger}$ & 72.9 & 74.6 \\
\hline Total Fertility Rate $(2002)^{\ddagger}$ & 2.75 & 2.27 \\
\hline \multicolumn{3}{|l|}{ Socioeconomic } \\
\hline$\%$ households with own water supply (on the household) (2000)* & 74.4 & 88.7 \\
\hline$\%$ households with dirt floor $(2000)^{*}$ & 38.4 & 14.8 \\
\hline$\%$ households without gas cooking facilities (wood/coal) (2000)* & 54.5 & 17.5 \\
\hline \% illiterate population (subjects aged over 14 years) $(2000)^{*}$ & 22.9 & 9.5 \\
\hline \% with wastewater disposal system (2000)* & 77.0 & 85.9 \\
\hline
\end{tabular}

Health

$\begin{array}{lll}\text { Standardized intestinal infectious disease mortality rate (per } 100000 \text { inhabitants) (2000) }{ }^{\ddagger} & 17.3 & 5.8\end{array}$

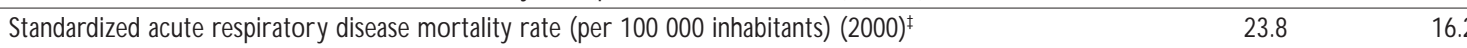

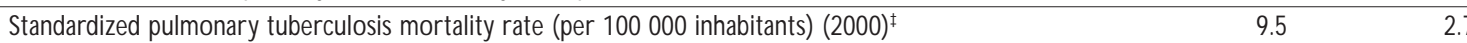

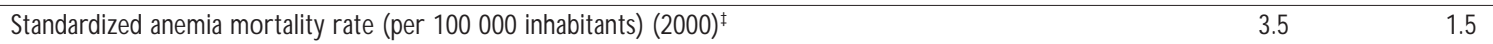

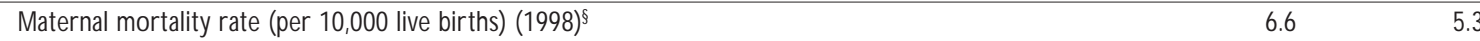

\% transmissible disease mortality (1999)\# $15.2 \quad 9.2$

Mean N 0. of years at death (1999)\#

49.8

56.7

References: 8-11

dominantly by peasants, with substantial indigenous settlements, mainly of the Mayan ethnic group Tojolabal. The majority of its inhabitants is engaged in agricultural work, has low purchasing power, and practically no social security. In fact, their health needs, as an "open population" (without social security), are satisfied only through state-provided health services, or through self-care, including the use of traditional medicine. $^{18}$

A random sample of communities was drawn from municipalities with high and very high poverty levels, considering their level of access to health services, as measured by the traveling time to the nearest health facilities ( $<1$ hour; 1 hour or more). The level of poverty proposed by the National Population Council, ${ }^{19}$ is based on an index using the 1990 census information, and nine indicators considered to be structural in nature (with little change over time), such as educational level, dwelling conditions, size of community, and monthly income. All municipalities in Mexico are classified according to this index into five levels of poverty (from very high to very low). In the border region, two of twelve municipalities are classified as having "very high" poverty levels (both of them were included in the sample), nine as "high" (five of them were selected by simple random sampling), and one is classified as having a "medium" poverty level (not included in the sample). On the other hand, the level of access to health services is one of the indicators used to measure the level of development of countries. ${ }^{20}$

Information was obtained from 1878 of the 1894 households that were selected (non-response rate of $0.84 \%$ ). A total of 11274 people were registered in these households. The total population in the study area (the municipalities with "high" and "very high" poverty levels) was estimated at 331437 persons, representing $9.0 \%$ of the population of Chiapas, distributed among 885 communities. ${ }^{18}$

A standardized health questionnaire (based on previous studies carried out in Chiapas) ${ }^{1,21-24}$ was administered to all adults in the households studied, which gathered demographic (age, sex, ethnic group), socioeconomic, and health and services usage information. The fieldwork was carried out by seven in- 
terviewers: four graduate students (two chemists, one biologist, and one social worker) and three people from the same region who spoke Tojolabal (the main Mayan language of the region), to translate when necessary. Of the total number of households, those with children under 15 years of age were identified, and one in every four of these households was systematically selected. Stool specimens were obtained from all the children aged between 1 and 14 years $(n=1478)$ in each of the households selected. In some households more than one child provided a specimen.

Mothers or guardians of all selected children were asked to obtain three stool specimens on three consecutive days starting the day following the interview. Mothers were instructed on how to collect the stool samples and were provided with one Copropac container per child, filled with Phenol-Alcohol-Formaldehyde (PhAF) preserving solution, ${ }^{25}$ and three wooden spatulas, each one to be used to obtain one stool specimen, which was subsequently incorporated into the PhAF solution. Fecal specimen containers were retrieved by fieldworkers from the collaborating households. The containers were sealed in polystyrene foam bins using parafilm, for storage and transportation from the communities under study to the laboratories of the Malaria Research Center (Ministry of Health), in Tapachula, Chiapas, where they were processed by the Faust Method by trained laboratory personnel. ${ }^{26}$

A total of 1160 children submitted three fecal specimens for analysis (response rate $78.5 \%$ ). The main reasons for not being able to process specimens from the remaining 318 children were as follows: $224 \mathrm{did}$ not respond, while the others either did not complete the three specimens, provided insufficient quantities, were currently taking anti-parasite medication, or the child was not at home during the study period. Although some indicators (locality, age and occupation of head of household) showed differences between excluded and included children, the groups were similar for gender, indigenous language spoken by head of household, and some characteristics of the households (Table II).

The study protocol was approved by local authorities and accepted by all adults in each study community (informed consent was requested at community meetings organized in each study village).

Positive enteroparasitosis was defined as the presence, whether scarce or abundant, of eggs, cysts, larvae, or parasites in the fecal specimen. To simplify the presentation of results, despite more parasites being identified, analysis was restricted to the three most prevalent and epidemiologically important (Entamoeba histolytica, Giardia lamblia, and Ascaris lumbricoides).

\section{Table II \\ Children's socioeconomic characteristics, Chiapas, Mexico, 1998}

\begin{tabular}{cccc} 
Variable & $\begin{array}{c}\text { Included children } \\
n=1160\end{array}$ & $\begin{array}{c}\text { Excluded children } \\
n=321\end{array}$ & $p$ \\
$\begin{array}{c}\text { Locality } \\
\text { Rural }\end{array}$ & $16.4 \%$ & $11.2 \%$ & $<0.03$ \\
\hline Urban & $83.6 \%$ & $88.8 \%$ &
\end{tabular}

Age

\begin{tabular}{llll}
$1-4$ years & $33.4 \%$ & $24.5 \%$ & $<0.05$ \\
\hline $5-9$ years & $35.9 \%$ & $31.4 \%$ & \\
\hline $10-14$ years & $30.7 \%$ & $44.0 \%$ & \\
Sex & & & \\
Male & $52.2 \%$ & $53.9 \%$ & 0.58 \\
\hline Female & $47.8 \%$ & $46.1 \%$ &
\end{tabular}

0 vercrowding (persons/bedroom)

\begin{tabular}{llll}
$<4$ & $24.1 \%$ & $26.5 \%$ & 0.37 \\
\hline$\geq 4$ & $75.9 \%$ & $73.5 \%$ &
\end{tabular}

O ccupation of head of household

\begin{tabular}{cccc} 
A griculture & $80.9 \%$ & $87.5 \%$ & $<0.05$ \\
\hline N o agriculture (other) & $19.1 \%$ & $12.5 \%$ & \\
& & & \\
ndigenous language spoken by head of household & & \\
N o & $76.3 \%$ & $78.5 \%$ & 0.40 \\
\hline Yes & $23.7 \%$ & $21.5 \%$ &
\end{tabular}

Have refrigerator

\begin{tabular}{lrrr} 
No & $88.2 \%$ & $92.5 \%$ & $<0.04$ \\
\hline Yes & $11.8 \%$ & $7.5 \%$ & \\
$\begin{array}{lrrr}\text { Cooking facilities } \\
\text { Wood/coal }\end{array}$ & & & \\
\hline Gas & $94.2 \%$ & $95.1 \%$ & 0.55 \\
\hline & $5.8 \%$ & $4.9 \%$ &
\end{tabular}

Electricity

\begin{tabular}{cccc} 
No & $84.7 \%$ & $81.0 \%$ & 0.12 \\
\hline Yes & $15.3 \%$ & $19.0 \%$ &
\end{tabular}

Floor

\begin{tabular}{llll} 
W ithout covering & $64.0 \%$ & $59.5 \%$ & 0.14 \\
\hline W ith covering & $36.0 \%$ & $40.5 \%$ & \\
& & & \\
$\begin{array}{l}\text { W astewater disposal system } \\
\text { N one }\end{array}$ & $23.9 \%$ & $22.7 \%$ & 0.67 \\
\hline Toilet, privy & $76.1 \%$ & $77.3 \%$ &
\end{tabular}

They were analyzed separately, given that bivariate analyses showed that joint distributions of the parasites were not significant (results not shown). The Faust method does not differentiate pathogenic and nonpathogenic amoebas such as Entamoeba dispar, there- 
fore our results are expressed as: Entamoeba histolytical Entamoeba dispar infection.

Bivariate relationships between the above mentioned parasites and factors possibly associated with their presence were assessed by the chi-square test, or Fisher's exact test, using the SPSS package for Windows, version 8.0. Multivariate analysis was performed using generalized linear models for correlated binary data for each parasite ${ }^{27-29}$ with SAS, PROC GENMOD. Models were adjusted for factors related to the presence of parasites in the bivariate analyses and according to epidemiological criteria. Therefore, the method used was the "enter" method.

\section{Results}

The mean age of study subjects was 6.8 years (standard deviation [SD] 3.9), with 33\% aged between 1 and 4 years, $36 \%$ aged 5 to 9 years, and $31 \% 10$ to 14 years. The percentage of males was 52.1. With respect to socioeconomic indicators, $64 \%$ lived in houses with dirt floors, $86 \%$ used wood as the cooking fuel, only $12 \%$ lived in houses having a refrigerator, and $24 \%$ lived in houses with no sewage disposal system.

At least one parasite was found in 776 of the children studied, yielding a global intestinal parasitosis prevalence of $67 \%$ (CI 95\%: 64-70\%). Of these $776,40 \%$ had one species of parasite, $43 \%$ had two, $15 \%$ had three, and $2 \%$ had four. The distribution of identified parasites was as follows: Entamoeba histolytica/Entamoeba dispar $51.2 \%$, Entamoeba coli $32.9 \%$, Giardia lamblia 18.3\%, Ascaris lumbricoides 14.5\%, Hymenolepis nana $1.5 \%$, Trichuris trichuria $0.8 \%$, and Iodamoeba butschlii $0.1 \%$.

Factors associated with a higher prevalence of Entamoeba histolytica/Entamoeba dispar (Table III) were: living in a locality classified as having very high poverty; head of household speaking an indigenous language; lack of a refrigerator in the home; river as the main source of water; and child's age between 1 and 4 years.

Factors associated with Giardia lamblia infection were: locality being classified as having very high poverty, head of household speaking an indigenous language; house with dirt floor; obtaining water from either a public well or from a river; and child's age between 1 and 9 years.

Finally, Ascaris lumbricoides was the parasite statistically associated with the greatest number of factors. Practically all household-related indicators denoting greater poverty were found to be associated with this helminth: lack of electricity, lack of refrigerator; use of wood as cooking fuel; dirt floor; water supply from communal source or river; overcrowding; and, as expected, living in a locality classified as having very high poverty; head of household speaking an indigenous language; and child's age between 10 and 14 years (Table III).

Table IV shows the models including only the variables associated with the presence of parasites, and the variables of epidemiological importance (such as age or overcrowding) in the study of each parasite, as well as other variables indicating the level of poverty (living conditions and educational level). Within the three models, only the variables age and indigenous language were found to be significantly associated with the presence of Entamoeba histolytica/Entamoeba dispar, while for Giardia lamblia the significant variables were those mentioned above and, additionally, the water source (Table IV). The variables associated with the presence of Ascaris lumbricoides were: water source, and two conditions related to characteristics of the home -having a refrigerator and having electricity. However, age and overcrowding were retained in the model due to their epidemiological importance in the study of this parasite (Table IV).

Finally, it should be noted that in the three models fitted, the correlation between children in the same home was below 0.2 .

\section{Discussion}

Study findings indicate a prevalence of $67 \%$ for intestinal parasitosis among the population 1 to 14 years of age in areas of high and very high poverty in the border region of Chiapas, Mexico, almost two thirds $(60 \%)$ of whom are infected with several parasites. Thus, in this region, intestinal parasitosis infection is a common phenomenon.

This fact is very important, given that Chiapas is one of the Mexican states with the highest rates of diarrheic diseases. It has the highest rate of death associated with diarrhea (four times higher than the rate for Mexico as a whole) and 50\% of these deaths occur among children aged under 15 years. ${ }^{30}$

The overall distribution of parasite prevalence is consistent with that found by most of studies undertaken in Mexico and in other countries, Entamoeba histolytica and Giardia lamblia being the most common protozoa, and Ascaris lumbricoides the most common helminth. ${ }^{31-34}$ However, the percentages do not coincide. This may be due to a variety of factors such as employment of differing diagnostic techniques (we were unable to differentiate between pathogenic amoebas and non-pathogenic ones such as Entamoeba dispar), geographical differences, or due to different de- 
Table III

FACTORS IDENTIFIED AS ASSOCIATED WITH THE THREE PREVALENT And epidemiologically important Parasites, Chiapas, MeXico, 1998

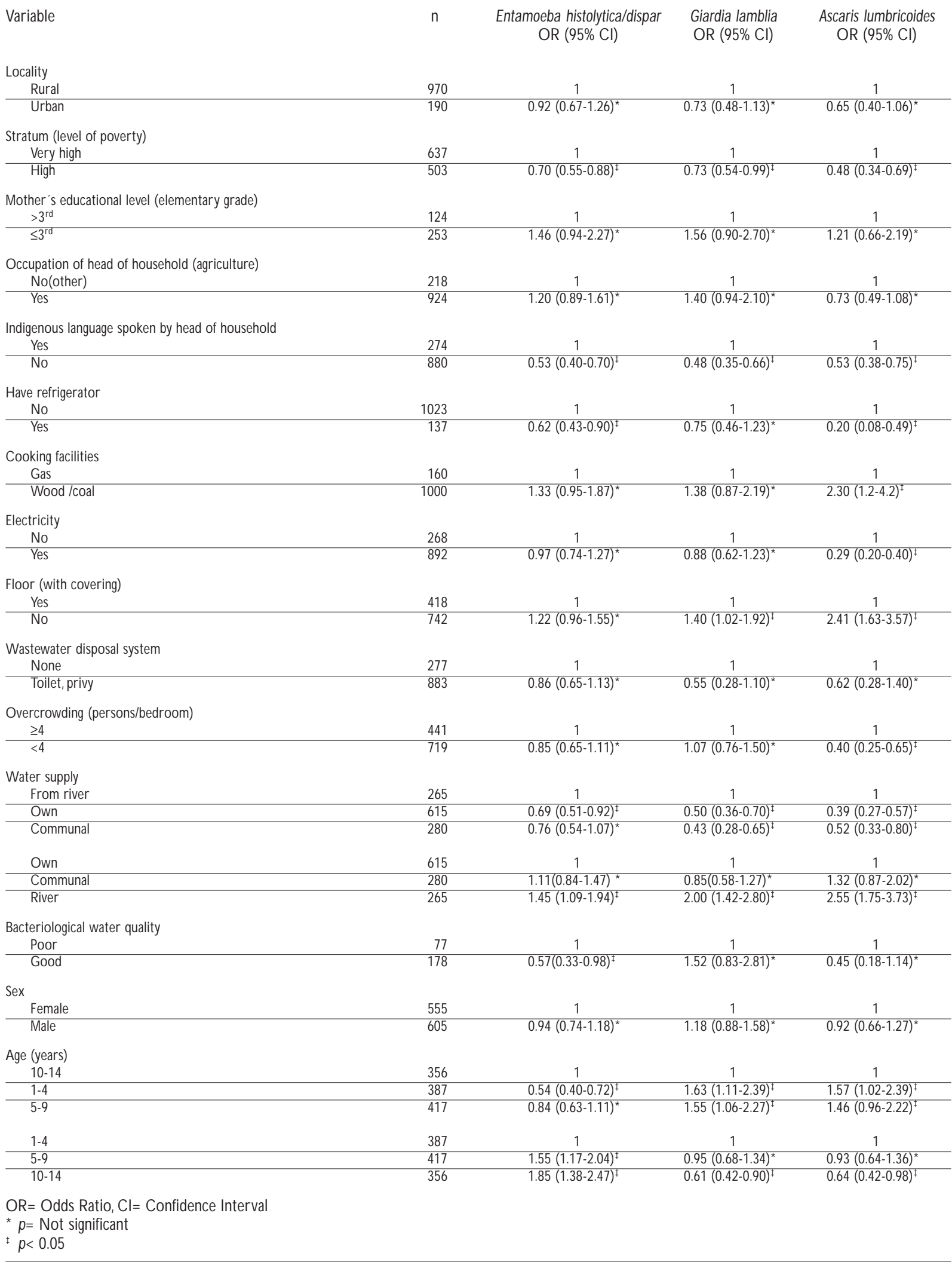




\section{Table IV \\ Multivariate analysis for Entamoeba histolytica/Entam Oeba DISPar, * Giardia lamblia, and Asc aris lumbricoides, ${ }^{\S}$ Chiapas, Mexico, 1998}

$\begin{array}{lll} & \begin{array}{c}95 \% \text { confidence } \\ \text { interval }\end{array} \\ \text { Variable } & \text { Odds Ratio }\end{array}$

Entamoeba histolytica/Entamoeba dispar

\begin{tabular}{llll} 
Age 1 - 4 years & 0.52 & 0.39 & 0.70 \\
\hline Age 5 - 9 years & 0.82 & 0.62 & 1.10 \\
\hline Indigenous language: N o & 0.52 & 0.37 & 0.73
\end{tabular}

Giardia lamblia

\begin{tabular}{llll} 
Age $1-4$ years & 1.55 & 1.06 & 2.26 \\
\hline Age 5- 9 years & 1.50 & 1.01 & 2.22 \\
\hline Indigenous language: N o & 0.62 & 0.41 & 0.94 \\
\hline W ater supply: own & 0.64 & 0.42 & 0.98 \\
\hline W ater supply: communal & 0.53 & 0.32 & 0.89
\end{tabular}

Ascaris lumbricoides

\begin{tabular}{llll} 
Age $1-4$ years & 1.32 & 0.85 & 2.07 \\
\hline Age 5 - 9 years & 1.31 & 0.84 & 2.06 \\
\hline W ater supply: own & 0.44 & 0.26 & 0.73 \\
\hline W ater supply: communal & 0.35 & 0.18 & 0.67 \\
\hline Refrigerator:Yes & 0.32 & 0.12 & 0.81 \\
\hline Electricity:Yes & 0.32 & 0.19 & 0.53 \\
\hline No overcrowding & 0.59 & 0.33 & 1.05
\end{tabular}

* Baseline group: age 10-14 years, head of household spoke some indigenous language. Baseline 0 dds: 2.29. Exchangeable correlation between children of the same home: 0.15

₹ Baseline group: age 10-14 years, head of household spoke some indigenous language, water obtained from river. Baseline odds:0.35. Exchangeable correlation between children of the same household: 0.12

$\S$ Baseline group: age 10-14 years, water obtained from river, no refrigerator, no electricity, overcrow ding. Baseline $0 \mathrm{dds}: 0.64$. Exchangeable correlation between children of the same household: 0.15

mographic and socioeconomic patterns of the populations studied (age, presence of indigenous groups, rural versus urban areas). ${ }^{35}$

One of the most important factors associated with the presence of protozoa was the head of household speaking an indigenous language. This condition probably reflects, on the one hand, the poverty level of the indigenous population studied, and on the other, problems in communication between these people and the health services: many indigenous people have difficulty in speaking Spanish, and doctors at health centers do not speak the indigenous language predominant in the region (almost 100\% of doctors working in health services in Chiapas speak no indigenous language). Both situations affect access to health services and to health information. At the same time, they can be associated with worse living conditions, ${ }^{18}$ as well as with habits, beliefs and health practices different from those promoted by institutional medicine. ${ }^{33}$

Age was also found to be significantly associated with the prevalence of protozoa (Entamoeba histolytical Entamoeba dispar and Giardia lamblia). A lower prevalence of Entamoeba histolytica/Entamoeba dispar was observed in the group aged from 1 to 4 years. This could be due to the fact that generally children in the areas where the other studies were carried out are breastfed beyond one year of age 1 , and it is not uncommon for breast-feeding to continue until two years or even longer (around 50\%, data not shown). Thus, children receive immunological protection through their mother's milk. ${ }^{36}$ Two additional factors must also be considered: that at this stage of infancy the child interacts less with its surroundings; and secondly that liquids other than breast milk are most commonly tea or coffee, thus ensuring that the water consumed has been boiled.

In contrast, a higher prevalence of Giardia lamblia parasitosis was found in the groups aged from 1 to 9 years, an association that has been reported by other authors. ${ }^{36-38}$ The highest prevalence was among those aged under 5 , which decreased as age increased. Once again, the coexistence of two factors could explain the higher prevalence of this parasite among the younger children: on the one hand immaturity of the humoral immune response, which plays a very important role in controlling Giardia lamblia infections but not so much in the case of Entamoeba histolytica, ${ }^{39}$ and on the other hand, the presence of malnutrition, to a greater or lesser extent, which in turn reduces both cellular and humoral immune defenses. ${ }^{40}$ Several studies have shown that Chiapas, along with Oaxaca, are the Mexican states with the highest height deficit rates. For example, among first grade elementary school children height deficit is $44.1 \%$, which contrasts with the national figure of $18.7 \%$, and more dramatically when compared to the state of Baja California (in the North of Mexico), where only $4.3 \%$ of such children have a height deficit. ${ }^{41}$ Another study carried out in 1996, an striking prevalence (51\%) of height deficit in Chiapas was found in children under five years. ${ }^{42}$

Regarding the association between Giardia lamblia parasitosis and obtaining water for domestic consumption directly from rivers, it is important to note that this practice makes it necessary to consider the possibilities of infection by this parasite. River water is an exposed source and it is vulnerable to a variety of types of contamination, not only environmental but also during its transport, usually in non-hygienic conditions. 
Although it has been reported that ascariosis shows convex prevalence and intensity patterns with age, ${ }^{27,43,44}$ in our study no significant association was found between age and the presence of ascariosis. Two plausible explanations for this fact can be advanced: firstly, it has been reported that Ascaris lumbricoides is more prevalent in children than adults, but its physiopathology is not associated with an individual's predisposition related to age in terms of growth; secondly, overcrowding among the population under study could affect this association (in the present study overcrowding was at the borderline of statistical significance). It should be pointed out that the literature which we consulted ${ }^{27,39,43-46}$ revealed that age is found to be a significant factor for Ascaris lumbricoides, precisely when overcrowding is not taken into account. However, in the multivariate analysis age was retained since it is traditionally associated with the presence of this helminth.

Similarly, Ascaris lumbricoides is also more prevalent in the less favored social classes, which may be explained by their closer contact with soil and harsh environmental conditions. ${ }^{38,43,46}$ Thus, lacking a refrigerator and electricity is an indirect measure of the family's economic situation and could be related to higher probabilities of food contamination. This should be taken into account precisely because it is in populations of this type that moderate or severe ascariosis infection has been associated with malnutrition and growth retardation in children. ${ }^{30}$

With regard to bacteriological water quality, the present study is limited when it comes to analyzing the relationship between the bacteriological quality of drinking water and the presence of parasites in the child. As we reported in another article, ${ }^{47}$ difficulties in access to the study area (geographical, climatic and those specific to the armed conflict that began in 1994), as well as budget problems, meant that water samples could only be obtained from 99 of the 1,874 households under study. In $67 \%$ of these 99 households the bacteriological quality of the water was poor (three or more CFU $/ 100 \mathrm{ml}$ of total coliforms). ${ }^{48}$ This finding, although based on a small sample, reflects the problems of drinking water contamination as well as the lack of adequate water supply systems in most of the communities, which are predominantly rural. In many studies, water contamination was associated with high intestinal parasitic infection. ${ }^{27,33}$

The variable maternal education level ${ }^{33}$ has been found to be significantly associated with parasitosis in other studies; however, in our survey it was not significant, there were not enough data (information was obtained from about 377 mothers) or most of the mothers from whom information was collected had very low education levels ( $<$ three years formal education).

Even so, it should be noted that the low correlation estimated by the three models suggests that the variables included explain well enough the presence or absence of intestinal parasitosis. In other words, it would appear that no important variables have been omitted which could help to significantly explain the clustering, in this case family- or household-related, of the variable under study.

\section{Conclusions}

The results obtained in the present study, along with the excessive death rates due to infectious intestinal diseases en Chiapas, highlight the compulsory nature of the need for programs to be developed to reduce the observed prevalence of parasitosis and to raise the quality of life and health of these highly deprived populations.

In the particular case of enteroparasitosis, urgent measures should be taken to improve water quality, sewage disposal and domestic hygiene, and to promote breast-feeding, as well as education policies aimed at reinforcing the use of indigenous languages by physicians in the health services.

\section{Acknowledgements}

The authors would like to express their gratitude to Alejandro Flores, María Luisa Estudillo, Roberto Solís, Trinidad Pérez (El Colegio de la Frontera Sur) and David Monterde (Universidad Autónoma de Barcelona, Spain) for their participation in data collection and data analysis; also to David McFarlane for his invaluable comments to this manuscript.

\section{References}

1. 0 choa-Díaz H, Sánchez-Pérez HJ, Ruiz-Flores M, Fuller M. Social inequalities and health in rural Chiapas, Mexico:Agricultural economy, nutrition, and child health in La Fraylesca Region. C ad Saude Publica, Río de Janeiro 1999;15:261-70.

2.W orld Health $\mathrm{O}$ rganization. Prevention and control of intestinal parasitic infections. Geneva:W HO , 1987; Technical report series N 749 . 3. Jemaneh L. Comparative prevalences of some common intestinal helminth infections in different altitudinal regions in Ethio pia. Ethiop Med J 1998:36:1-8.

4. Long Q i Xu, Sen Hai Yu, Ze Xiao Jiang, Jia Lun Yang, Chang Q iu Lai, $X$ iang Jun $Z$ hang et al. Soil transmitted helminthiases: $N$ ationwide survey in China. Bull W orld Health $O$ rgan 1995;73:507-513.

5. Callender J, Grantham-MCG regor SM,W alker S, Cooper E. Trichuris infection and mental development in children. Lancet 1992;339:181. 6. N okes C, Grantham-McG regor S, Sawyer A, Cooper E, Bundy DAP. Parasitic helminth infection and cognitive function in schoolchildren. Proc R Soc Lond. B Biological Sci 1992;247:77-81.

salud pública de méxico / vol.45, no.5, septiembre-octubre de 2003 
7. Pan A merican Health O rganization. La salud en las A méricas, 1998. [serial on line]; II: 403 - 418. W ashington, DC: PAH O, 1998. Available from: URL: http://www.paho.org/Spanish/SHA/HIA 1998ed.htm. 8. Instituto $\mathrm{N}$ acional de Estadística, G eografía e Informática.Tabulados básicos nacionales y por entidad federativa. XII Censo General de Población yVivienda 2000. México, DF: IN EGI, 2001.

9. Secretaría de Salud, Dirección General de Información y Evaluación del Desempeño. Sistema N acional de Información en Salud (SIN AIS). México, DF:SSA, 2003. Disponible también en: http://www.ssa.gob.mx. 10. Secretaría de Salud. La situación de los estados, 1999. México, DF: SSA, 2001.

11. Secretaría de Salud. D irección General de Estadística e Informática. Principales resultados de la estadística sobre mortalidad en México, 1999. Salud Publica Mex 2001;43:67-73.

12. Consejo N acional de Población. La situación demográfica de México. 2a. ed. México, DF: Conapo, 1998.

13. Sánchez-Pérez HJ, 0 choa-Díaz H, Miranda- 0 campo R. La situación de salud en Chiapas: consideraciones para su análisis. En: Miranda O R, Valqui $C$, ed. Chiapas: el regreso a la utopía. México, DF: Ed. Comuna, Universidad Autónoma de Guerrero, 1995:63-80.

14. Secretaría de Salud. Dirección General de Estadística e Informática. Principales resultados de la estadística sobre mortalidad en México, 1997. Salud Publica Mex 1998;40:517-523.

15.Tay J, Ruiz A, Schenone H, Robert L, Sánchez-Vega J, U ribarren T et al. Frecuencia de las protozoosis intestinales en la República Mexicana. Bol Chil Parasitol 1994;49:9-15.

16. Secretaría de Medio Ambiente, Recursos N aturales y Pesca, Comisión N acional del Agua. Programa Hidráulico de Gran Visión 2001-2025. D ocumento preliminar para análisis en el Consejo Consultivo $\mathrm{N}$ acional para el Desarrollo Sustentable, México, DF: SEMARN AP, CN A, 2001.

17. Sánchez-Pérez HJ, Jansà JM, Martín-Mateo M. Hacia un mejor control de la tuberculosis pulmonar en el estado de Chiapas, México. San C ristóbal de las $C$ asas: El Colegio de la Frontera Sur, Instituto Municipal de la Salud de Barcelona, Universidad Autónoma de Barcelona, 1996. 18. Sánchez-Pérez HJ.Tuberculosis pulmonar en zonas de alta marginación socioeconómica de Chiapas, México: problemas y retos a superar. El C aso de la Región Fronteriza [tesis doctoral]. Barcelona: Universitat Autònoma de Barcelona, 1999.

19. Consejo N acional de Población. Indicadores socioeconómicos e índice de marginación municipal, México 1990. México, DF: Conapo, 1993.

20.The W orld Bank.W orld Development Report 1997. The state in a changing world.W ashington: O xford University Press, 1997.

21. Gobierno del Estado de Chiapas, Secretaría de Desarrollo Social del Estado de Chiapas. La marginación por localidad en cifras 2000 (versión disco compacto).Tuxtla Gutiérrez, Chiapas: Gobierno del Estado de Chiapas, 2002.

22. Sánchez-Pérez HJ, 0 choa-D íaz H, G arcía-Gil M, Martín-Mateo M. Bienestar social y servicios de salud en la Región Fraylesca de Chiapas: el uso de servicios de atención prenatal. Salud Publica Mex 1997;39:530-538.

23. Sánchez-Pérez HJ, García-Gil M, Halperin D. Pulmonary tuberculosis in the Border Region of C hiapas, Mexico. Int J Tuberc Lung D is 1998;2:37-43.

24. 0 campo-Torres M, Sánchez-Pérez HJ, N azar-Beutelspacher A, Castro-Ramírez AE, Cordero-0 campo B. Factores asociados a la colonización por Streptococcus del grupo B en mujeres embarazadas de Ios Altos de Chiapas. Salud Publica Mex 2000;42:413-421.

25. Cruz-López A, Cortés R, Valerdí G, G onzález E. U so masivo de la coproparasitoscopía con FAF. Salud Publica Mex 1989:31:536-540.

26. Giono-Cerezo S, Escobar-Guitérrez A,Valdespino JL, ed. Diagnóstico de laboratorio de infecciones gastrointestinales. México, D F: Secretaría de Salud, Instituto N acional de Diagnóstico y Referencia

Epidemiológicos, 1994:411-432.

27. Curtale F, Pezzotti P, Saad Y,A Aloi A.An analysis of individual, household, and environmental risk factors for intestinal helminth infection among children in Q ena Governorate, Upper Egypt. J Trop Pediatr 1999:45:14-17.

28. Lipsitz S, Kim K, Zhao L.Analysis of repeated categorical data using generalized estimating equations. Stat Med 1994;13:1149-1163.

29. Liang K, Z eger S. Longitudinal data analysis using generalized linear models. Biometrika 1986; 73:13-22.

30.Valdespino-Gómez JL, García-García ML, D el Río ZA, Salcedo RA. Magnitud y trascendencia de las infecciones gastrointestinales. Medidas de intervención. En: Giono CS, Escobar GA,Valdespino-Gómez JL, ed. Diagnóstico de laboratorio de infecciones gastrointestinales. México, DF: Secretaría de Salud, Instituto $N$ acional de Diagnóstico y Referencia Epidemiológicos, 1994:3-50.

31. N ewman RD, Moore SR, Lima AAM, N ataro JP, G uerrant RL, Sears CL.A longitudinal study of Giardia lamblia infection in north-east Brazilian children. Trop Med Int Health 2001;6:624-634.

32. Mahfouz AA, el-Morsgedy H, Farghaly A, Khalil A. Ecological determinants of parasitic infections among pre-school children in an urban squatter settlement of Egypt. J Trop Pediatr 1997;43:341-344. 33. De Silva N R, Jayapani VP, De Silva HJ. Socioeconomic and behavioral factors affecting the prevalence of geohelminths in preschool children. Southeast Asian J trop Med Public Health 1996;27:36-42.

34. 0 mar MS, Abu-Zeid HA, Mahfouz AAR. Intestinal parasitic infections in shoolchildren of A bha (Asir), Saudi Arabia. Acta Trop 1991;48:195202.

35. N avarrete-Espinoza J, N avarrete-C adena E, Escandón-Romero C, Escobedo-de la Peña J. Prevalencia de parasitosis intestinal en la población infantil de Santiago Jamiltepec, 0 axaca. Rev Med Inst Mex Seguro Soc 1993;31:157.

36. Islam A, Stoll BJ, Ljungstrom I, Biswas J, N azrul H, Huldt G.The prevalence of Entamoeba histolytica in lactating women and in their infants in Bangladesh. Trans R Soc Trop Med Hyg 1988;82:99-103. 37. Lunn PG, Erinoso HO, N orthrop-Clewes CA, Boyce SA. Giardia intestinalis is unlikely to be a major cause of the poor growth of rural Gambian infants. N utr 1999;129:872-877.

38. Birkhead G,Vogt R. Epidemiologic surveillance for endemic Giardia lamblia infection in Vermont.The roles of W aterborne and person-to person transmission. Am J Epidemiol 1989;129:762-768.

39. Botero D, Restrepo M. Parasitosis humanas. Medellín, Colombia: Ed Corporación para Investigaciones, 1998:27-135.

40.A merican A cademy of Pediatrics. N utrition and Immunity. En:AAP, Ed. Pediatric N utrition Handbook. Illino is (IL):AAP, 1998:473-483. 41. Secretaría de Educación Pública, Sistema para el Desarrollo Integral de la Familia. Segundo Censo N acional de Talla en $\mathrm{N}$ iños de Primer Grado de Primaria. México. Salud Publica Mex 1998;40:215.

42.A vila-C uriel A, Shamah T, Chávez-Villasana A. Encuesta N acional de Alimentación y N utrición en el Medio Rural 1996. Resultados por entidad.Volumen 1. México, DF: Instituto $\mathrm{N}$ acional de la $\mathrm{N}$ utrición Salvador Zubirán, Subdirección General de Nutrición de Comunidad, 1997:56.

43. U donsi JK, Behnke JM, G ilbert FS. A nalysis of the prevalence of infection and associations between human gastrointestinal nematodes among different age classes living in the urban and suburban communities of Port Harcourt, N igeria. Helminthology 1996;70:75-84. 44. 0 campo-Gómez G, Salgado-Cuevas R, Román-Bobadilla J. La omnipresencia de las helmintiasis. Salud Publica Mex 1992;34:357-360. 45. Hagel I, Lynch N R, Pérez M, Di Prisco MC, López R, Rojas E. Relationship between the degree of poverty and the lgE response to Ascaris infection in slum children. Trans R Soc Trop Med Hyg 1993;87: 16-18. 
46. Cooper E. Intestinal parasitosis and the modern description of the disease of poverty. Trans R Soc Trop Med Hyg 1991;85:168-170. 47. Sánchez-Pérez HJ,Vargas-Morales MG , Méndez-Sánchez JD. C alidad bacteriológica del agua para consumo humano en zonas de alta marginación de Chiapas. Salud Publica Mex 2000;42:397-406.
48. Secretaría de Salud. N orma oficial mexicana N O M 127-SSA I-1994, para la salud ambiental, agua para uso y consumo humano. Límites permisibles de calidad y tratamiento a que debe someterse el agua para su potabilización. México, DF: Diario 0 ficial de la Federación, 18 de enero de 1996:41-45. 